\title{
Aza-aziridinofullerene: Interconversion between Aza-aziridinofullerene and Bisazafulleroid
}

\author{
Puthuparampil P. Kanakamma, Shou-Ling Huang, Chiun-Gung Juo, \\ Guor-Rong Her, and Tien-Yau Luh*
}

\begin{abstract}
The synthesis and spectroscopic characterization of a novel bisazafulleroid (12) and aza-aziridinofulleroid (13) are described. Treatment of $\mathrm{C}_{60}$ fullerene with the $C_{2}$-chiral bisazide $\mathbf{1 1}$ in refluxing chlorobenzene afforded bisazafulleroid $\mathbf{1 2}$ in $20 \%$ yield. When a solution of $\mathbf{1 2}$ was exposed to ambient light a quantitative conversion to the more polar $\mathbf{1 3}$, in which the two imino groups add at both $[5,6]$ and $[6,6]$-ring junctions, was observed. The two compounds exhibited characteristic absorption profiles in the electronic spectra and also showed distinct CD curves. Further, thermolysis of $\mathbf{1 3}$ in refluxing toluene resulted in a clean conversion to $\mathbf{1 2}$ within 10 min. ${ }^{15} \mathrm{~N}$-labeled $\mathbf{1 2}$ and $\mathbf{1 3}$ were synthesized to establish the structures. These observations provide the first example of an interconversion between an azaand an aziridinofulleroid.
\end{abstract}

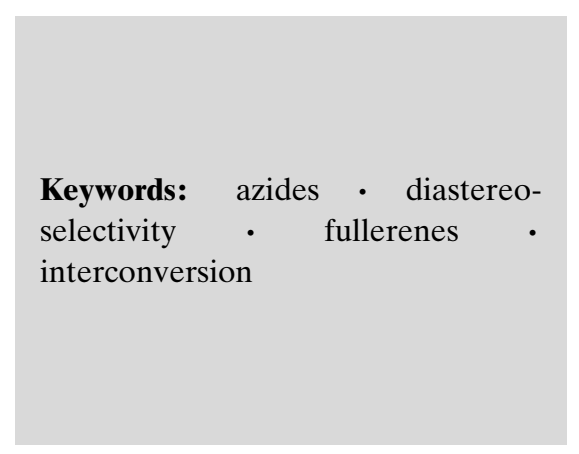

\section{Introduction}

Cycloaddition of organic azides to fullerene has been extensively investigated. ${ }^{[1-7]}$ The nature of the azide appears to play a pivotal role on the selectivity of the reaction. In addition to monoadducts, it can add onto two [5,6]-ring junctions of an acenaphthene ${ }^{[3]}$ or fluorene ${ }^{[4,5]}$ unit giving rise to regioisomers of bisazafulleroids. Alternatively, addition at the [6,6]-ring junctions of a phenanthrene unit has been observed $^{[5,6 b]}$ and the corresponding $N$-alkoxycarbonyl derivatives surprisingly yield the ring-opening adducts. ${ }^{[6]}$ In our earlier report, we demonstrated ${ }^{[5]}$ that the addition initially generates triazoline derivative $\mathbf{1}$, which upon thermolysis gives aziridinofullerene $\mathbf{2}$ and/or azafulleroid $\mathbf{3}$ via dipolar or biradical intermediates. It is noteworthy that bisazafulleroids 3-5 are thermally stable and there is no interconversion between $\mathbf{2}$ and 3. ${ }^{[4 a, b]}$ Recent reports from Mattay's group have shown the first photochemical rearrangement of an azafulleroid to aziridinofullerene. ${ }^{[2 \mathrm{k}]}$ Triazolinofullerene derivative $\mathbf{6}$ gives aziridinofullerene $\mathbf{7}$ on photolysis, whereas thermolysis gives azafulleroid 8. Irradiation of $\mathbf{8}$ at $300 \mathrm{~nm}$ gave $\mathbf{7}$ exclusively. Similar rearrangements have been shown to occur

[*] Prof. T.-Y. Luh, Prof. G.-R. Her, Dr. P. P. Kanakamma,

Dr. C.-G. Juo, S.-L. Huang

Department of Chemistry, National Taiwan University, Taipei

Taiwan 106 (Republic of China)

Fax: (+886)2-2364-4971

E-mail: tyluh@ccms.ntu.edu.tw

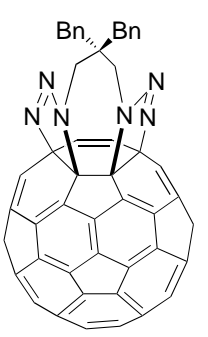

1

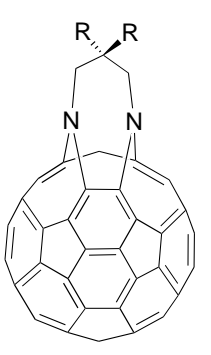

$3 \mathrm{R}=\mathrm{Bn}$

$4 \mathrm{R}=\mathrm{H}$

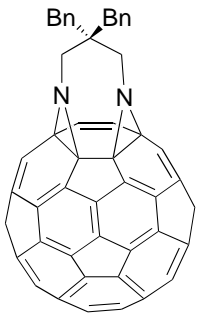

2

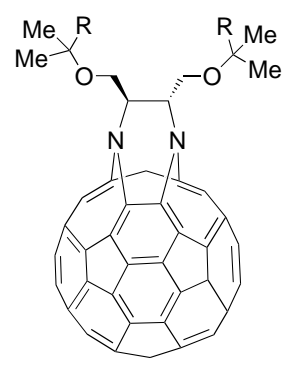

$5 \mathrm{a} \mathrm{R}=\mathrm{Me}$

$5 b \mathrm{R}=\mathrm{Bn}$ in the corresponding carbon analogues. ${ }^{[8]}$ The pioneering works of Wudl, Diederich, and others ${ }^{[9]}$ have shown that from the addition of carbene transfer reagents, such as diazo compounds to $\mathrm{C}_{60},[5,6]$-open fulleroids were obtained as the kinetic products, which underwent rearrangement to give the 


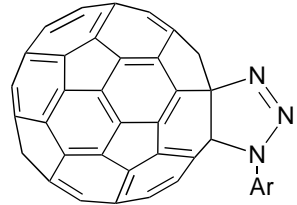

6

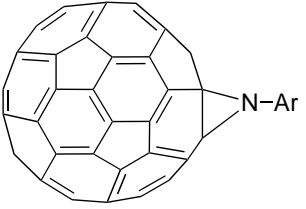

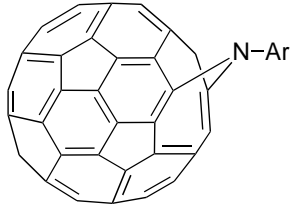

8

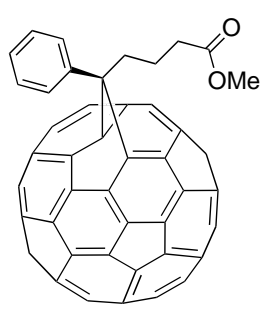

9

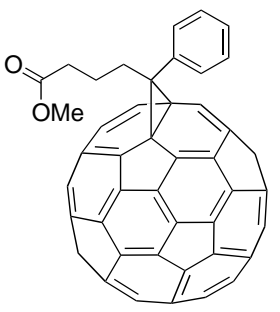

10 thermodynamically stable [6,6]-closed methanofullerenes. Indeed this conversion was found to occur photochemically, ${ }^{[10]}$ electrochemically, ${ }^{[11]}$ and under acid catalysis. ${ }^{[12]}$ Wudl proposed a di- $\pi$-methane rearrangement ${ }^{[10]}$ in the photochemical conversion of the [5,6]-open fulleroid 9 to the [6,6]-closed methanofullerene 10. This was supported by the observations of Shevlin ${ }^{[13]}$ who demonstrated a photochemical step in the thermal rearrangement of a cyclopentylidene fulleroid to a methanofullerene. It is noteworthy that the rearrangement of methanofullerenes, or their imino analogues, back to the corresponding fulleroids has not been explored. In this paper we report the first example of an interconversion between a bisazafulleroid (12) and aza-aziridinofulleroid (13).

\section{Results and Discussion}

Bisazide 11, obtained from 2,3-O-isopropylidene-Lthreitol, afforded $\mathbf{1 2}$ in $20 \%$ yield as a blackish brown solid, on treatment with $\mathrm{C}_{60}$ in refluxing chlorobenzene for $15 \mathrm{~h}$, followed by a rapid workup and flash column chromatography on silica gel. The FAB-MS showed an $[M+1]$ peak at $m / z=877.5$. In the ${ }^{13} \mathrm{C}$ NMR spectrum (Figure 1a), the $C_{1}$ symmetry is reflected by the 57 signals in the region $\delta 156-130$, including three signals with an intensity of 2 , in addition to the seven absorptions due to the tethering chain. The UV/visible spectrum of $\mathbf{1 2}$ (Figure 2) was found to be almost identical to that of the bisazafulleroid 4, ${ }^{[4]}$ in which the addition occurs at the two [5,6]-ring junctions of a fluorene unit.

${ }^{13} \mathrm{C}$ NMR investigations on ${ }^{15} \mathrm{~N}$-labeled (50\%) $\mathbf{1 2}$ clearly established the structure. Two sets of doublet of doublets at $\delta=155.99\left(J_{\mathrm{C}-\mathrm{N}}=10.4,4.1 \mathrm{~Hz}\right)$ and $137.72\left(J_{\mathrm{C}-\mathrm{N}}=6.6,2.4 \mathrm{~Hz}\right)$ were observed. These signals along with two doublets at $\delta=136.27$ $\left(J_{\mathrm{C}-\mathrm{N}}=13.4 \mathrm{~Hz}\right)$ and $138.75\left(J_{\mathrm{C}-\mathrm{N}}=5.0 \mathrm{~Hz}\right)$ can be readily assigned to those carbons of the fullerene core connected to the two nitrogen atoms. The large coupling constant observed at $\delta=136.27$ implies that the orientation of the lone pair of electrons on nitrogen atoms may contribute to this interaction. ${ }^{[14]}$ Four additional doublets at $\delta=137.80,135.69,134.41$, 132.98 along with a broad line at $\delta=130.04$ due to long-range coupling were also observed. The two tertiary carbons at $\delta=$ 81.52 and 78.37 resolved into a doublet. The two methylene carbons attached to two nitrogen atoms were observed as doublets with large coupling constants. An important feature of this ${ }^{13} \mathrm{C}$ NMR spectrum is the relatively downfield signal at $\delta=155.99$. For the ${ }^{15} \mathrm{~N}$-labeled compound, unlike the signal at $\delta=137.72$ that showed the expected splitting pattern, this

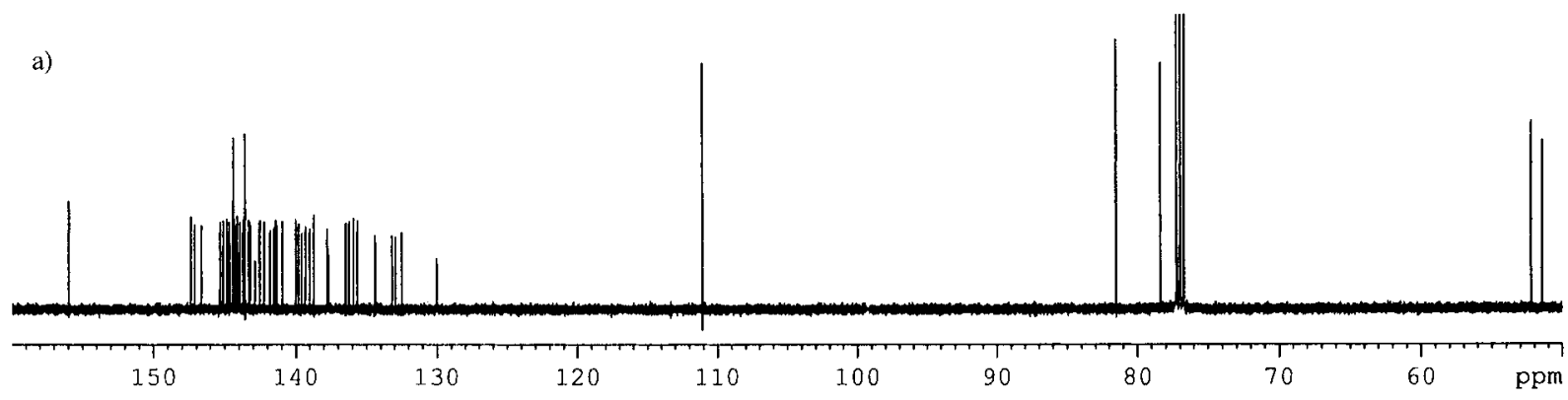

b)

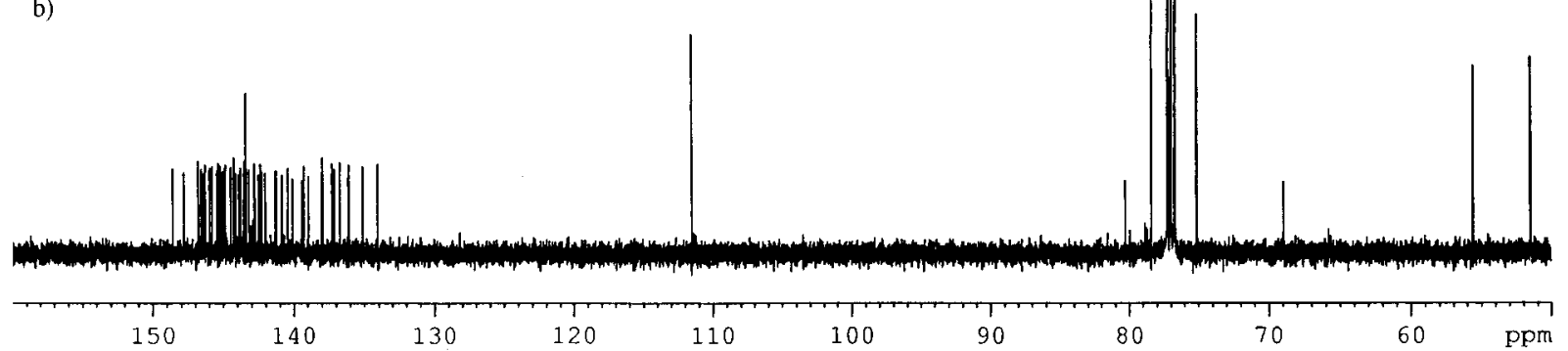

Figure $1 .{ }^{13} \mathrm{C}$ NMR spectra of a) $\mathbf{1 2}$ and b) $\mathbf{1 3 .}$ 


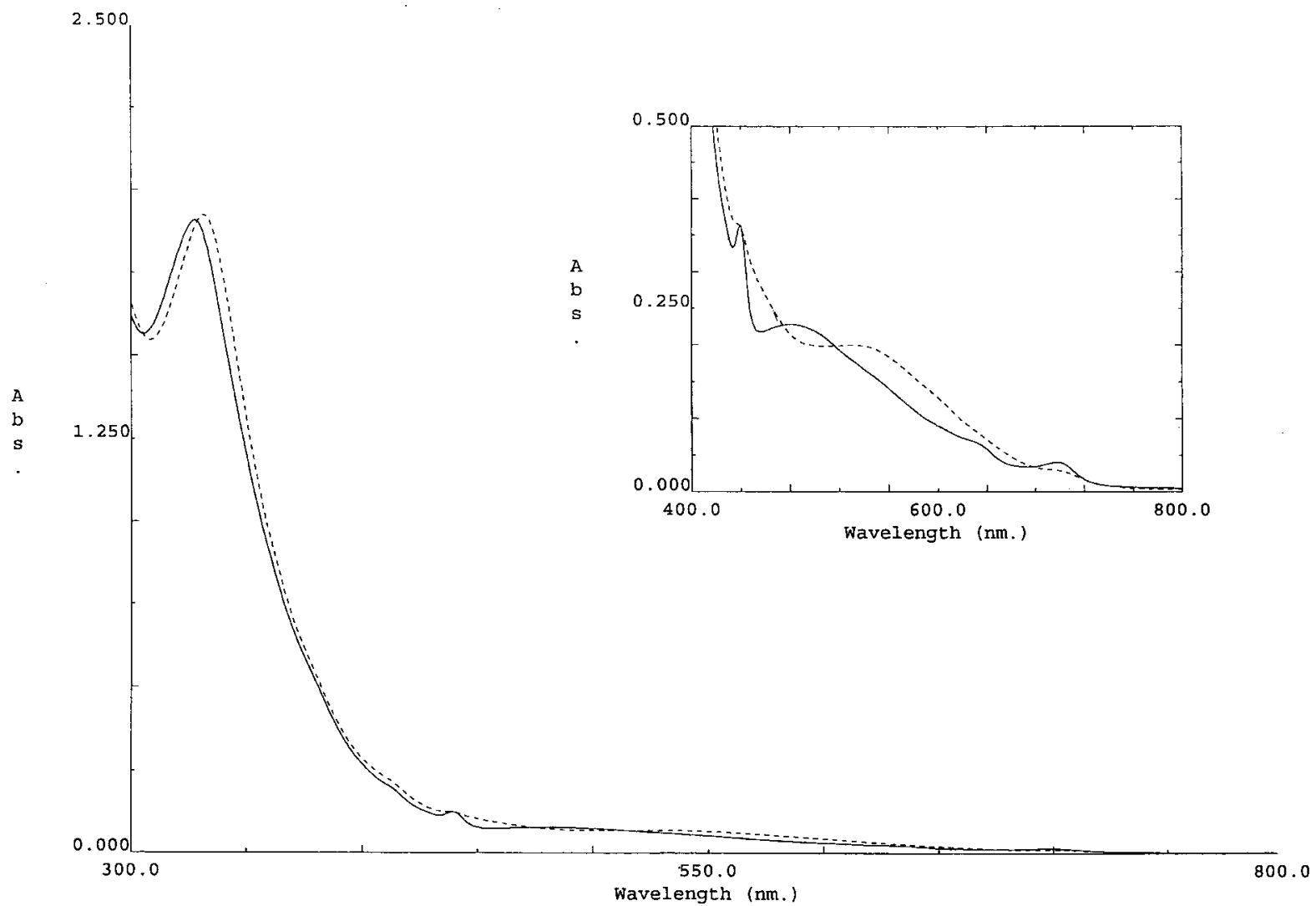

Figure 2. UV/Vis spectra for $\mathbf{1 2}$ (dotted line) and $\mathbf{1 3}$ (solid line) in toluene $\left(c=4 \times 10^{-5} \mathbf{M}\right.$; inset: $\left.c=1.2 \times 10^{-4} \mathrm{M}\right)$.

signal at $\delta=155.99$ resolved into five lines with a relative intensity of roughly $3: 7: 2: 3: 1$. This indicates that there is significant isotopic shift, so that some of the absorptions come very close and appear as broad lines. From all these observations we infer that the tethering moiety is rigid and therefore it may be strained. This is also reflected in the ${ }^{1} \mathrm{H}$ NMR spectrum of $\mathbf{1 2}$ in which two of the methylene protons appeared at comparatively low field, one as doublet of doublets at $\delta=4.38$ and the other around $\delta=4.7$ overlapped with other signals.

Compound $\mathbf{1 2}$ is stable in the dark. However, when a solution of $\mathbf{1 2}$ in chlorobenzene, toluene, toluene/hexane mixture, chloroform, or dichloromethane was exposed to ambient light, a quantitative conversion to the more polar 13 was observed. The electronic absorption spectrum showed significant difference in the visible region with characteristic absorptions at 439 and $698 \mathrm{~nm}$ indicative of a [6,6]-closed adduct (Figure 2). Further, the two compounds exhibited distinct circular dichroism (CD) curves (Figure 3). In the ${ }^{1} \mathrm{H}$ NMR spectrum, the two sets of methyl protons appeared as two sharp singlets at $\delta=1.62$ and 1.65 . The remaining six protons appeared in the region $\delta=3.86-5.08$ and exhibited a totally different spectral pattern compared with $\mathbf{1 2}$. In the ${ }^{13} \mathrm{C}$ NMR spectrum of $\mathbf{1 3}$ (Figure 1b), the two $\mathrm{sp}^{3}$ carbons corresponding

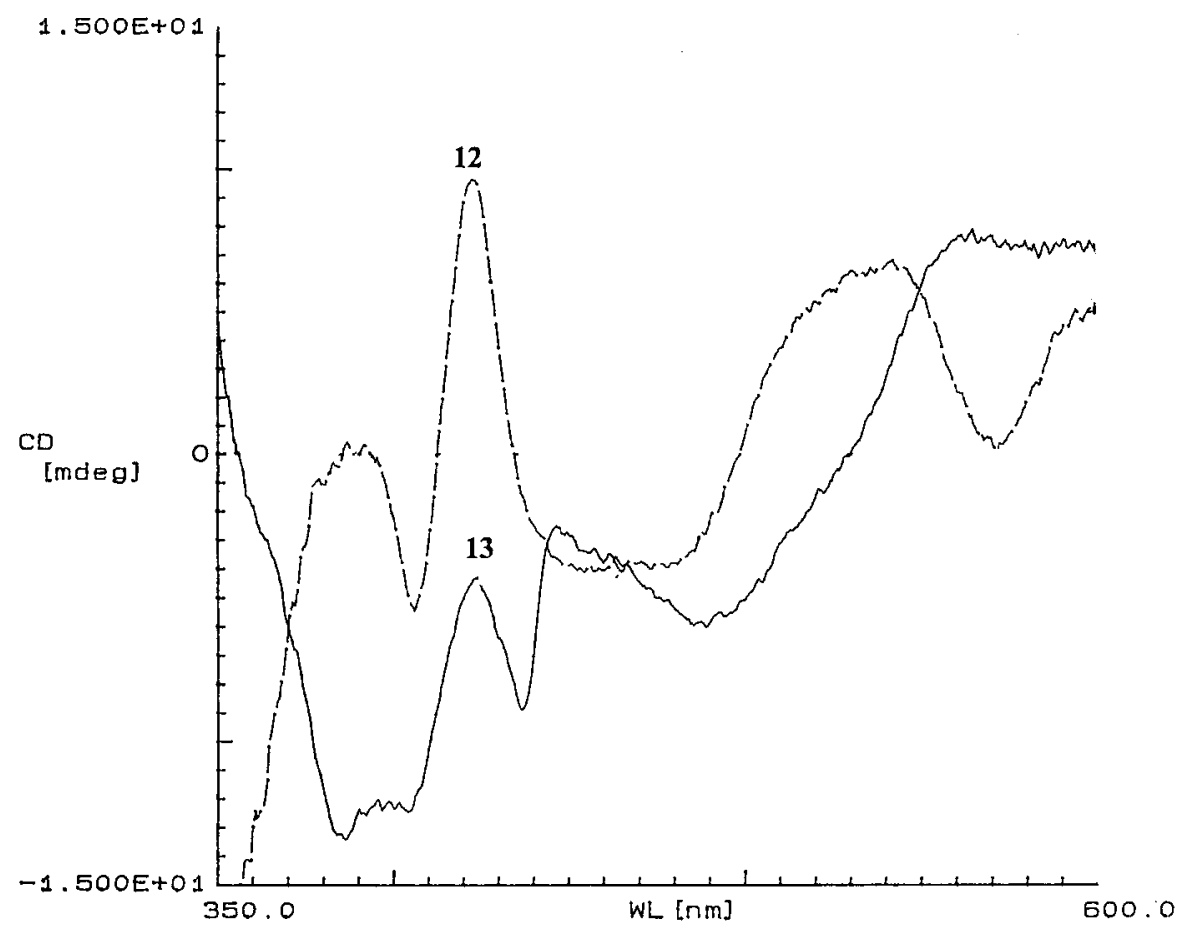

Figure 3. CD curves for $\mathbf{1 2}$ and $\mathbf{1 3}$ in toluene $\left(c=4 \times 10^{-5} \mathrm{M}\right)$. 
to the fullerene core appeared at $\delta=69.0$ and 80.30, in addition to signals due to other $\mathrm{sp}^{3}$ carbons. The remaining fullerene carbons appeared as 57 lines with one having an intensity of 2. Apparently, one of the imino groups in $\mathbf{1 2}$ undergoes ring closure at one of the ring junctions resulting in the formation of an aza-aziridinofulleroid. Three possible structures can arise as a result of this ring closure (Scheme 1). One is a direct $[5,6]$-ring closure to give $[5,6]$-open-[5,6]- aziridine carbon at $\delta=69.0$ exhibited long-range coupling, an indication of the close proximity of the second nitrogen atom. ${ }^{[15]}$ Since the splitting pattern and coupling constants of this carbon are comparable to those of the signal at $\delta=155.99$ of the bisazafulleroid, it appears that these carbons exhibit isotopic shifts to the same extent.

Thermolysis of $\mathbf{1 3}$ in refluxing toluene resulted in a clean conversion to $\mathbf{1 2}$ within $10 \mathrm{~min}$ [Eq. (1)]. It should be mentioned that $\mathbf{1 2}$ was also obtained by heating a solid sample of $\mathbf{1 3}$ at $100{ }^{\circ} \mathrm{C}$ for $1 \mathrm{~h} .{ }^{1} \mathrm{H}$ NMR, UV-Vis

$12 \stackrel{\text { light, RT }}{\underset{110^{\circ} \mathrm{C}}{\rightleftharpoons}} \mathbf{1 3}$

spectroscopy or $\mathrm{CD}$ experiments can be used for monitoring the interconversion. In our experiments we found that, in the conversion of $\mathbf{1 2}$ to $\mathbf{1 3}$, a solution of 12 in $\mathrm{CDCl}_{3}$ in an NMR tube, when protected from ambient light showed no change in the spectral pattern even after two weeks. However, when this solution was exposed to ambient light a clean conversion occurred. So it is evident that, as in the case of methanofullerenes, a photochemical rearrangement is taking place. The driving force may be the strain associated with the tethering chain, so that migration occurs even in ambient light. It was observed that the thermal conversion of the aziridine to the aza derivative proceeds even in the dark. The thermal rearrangement of annelated azepines has been reported. ${ }^{[16]}$ So it is anticipated that under thermal activation a 1,5sigmatropic shift takes place to give intermediate $\mathbf{1 8}$, which can then undergo a disrotatory ring opening to regenerate the azafulleroid $\mathbf{1 2}$ (Scheme 2).

It is worth noting that the conversion of $\mathbf{1 2}$ to $\mathbf{1 3}$ is highly stereoselective. In the NMR spectrum of $\mathbf{1 2}$, two of the methylene protons and one carbon atom showed unusual downfield shift. Accordingly, it is likely that this strained imino moiety preferably undergoes rearrangement to afford 13. However, in the case of 13, spectral evidence indicates that the strain is not completely relieved and possibly under thermal activation this group again closed 14 (path 1). Secondly, [5,6]-ring closure followed by a 1,5 -sigmatropic shift in a similar manner to that found in the di- $\pi$-methane rearrangement ${ }^{[10]}$ to form the $[5,6]$-open- $[6,6]$ closed fulleroid. In this case there are two possibilities. The nitrogen can migrate to either position $a$ to give $\mathbf{1 5}$ (Scheme 1, path 2 ) or position $b$ leading to $\mathbf{1 3}$ (path 3 ). In order to differentiate between these possibilities, the ${ }^{13} \mathrm{C}$ NMR of the ${ }^{15} \mathrm{~N}$-labeled $\mathbf{1 3}$ was investigated. The methylene carbon at $\delta=51.50$ split into a doublet of doublets and that at $\delta=55.59$ into a doublet. It is interesting to note that one of the methine carbons exhibited long-range coupling with both nitrogen atoms, whereas the other one showed only broadening. Five additional doublets were observed at $\delta=134.08\left(J_{\mathrm{C}-\mathrm{N}}=5.3 \mathrm{~Hz}\right), 137.99$ $\left(J_{\mathrm{C}-\mathrm{N}}=6.0 \mathrm{~Hz}\right), 139.45\left(J_{\mathrm{C}-\mathrm{N}}=7.0 \mathrm{~Hz}\right), 142.06\left(J_{\mathrm{C}-\mathrm{N}}=\right.$ $2.6 \mathrm{~Hz})$, and $148.65\left(J_{\mathrm{C}-\mathrm{N}}=5.3 \mathrm{~Hz}\right)$. It is important to note that none of these fullerene carbon absorptions, other than the one at $\delta=69.0$ that corresponds to one of the $\mathrm{sp}^{3}$ carbons, appeared as doublet of doublets, whereas a minimum of two absorptions involving both ${ }^{1} J$ and ${ }^{2} J$ couplings might be expected for structures $\mathbf{1 4}$ and 15. Accordingly, these structures were ruled out. Hence the migration may follow path 3 giving compound 13. We were not surprised to see that the

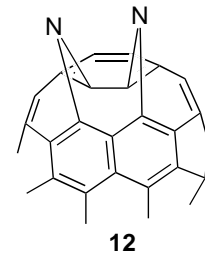

light,RT

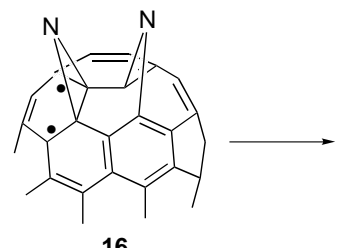

16

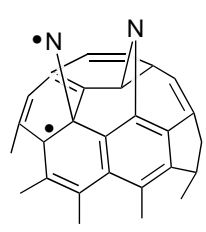

17

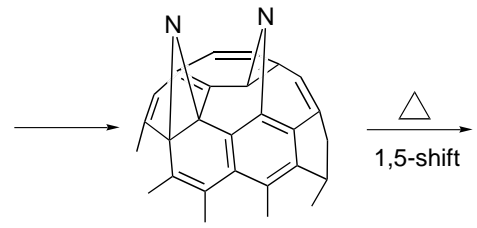

13

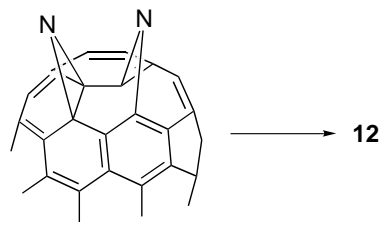

18
Scheme 2. Possible mechanism for the interconversion between $\mathbf{1 2}$ and $\mathbf{1 3}$ (substituent on nitrogen omitted for clarity). 
migrates back to regenerate $\mathbf{1 2}$. In other words, the strain in $\mathbf{1 2}$ and $\mathbf{1 3}$ serves as the driving force for this back and forth migration of the imino group on the surface of $\mathrm{C}_{60}$, and this rearrangement is highly diastereoselective. The NMR assignments very clearly demonstrate this facial selectivity in the migration. This reversible rearrangement under very mild conditions is of special synthetic interest especially when regio- and stereoselective additions to $\mathrm{C}_{60}$ are very difficult. The transfer of chiroptical properties from addends to the fullerene core is well documented. ${ }^{[17]}$ Our results suggest that desymmetrization of $\mathrm{C}_{60}$ by means of a chiral addend may influence the diastereoselectivity in further reactions onto the fullerene skeleton.

\section{Experimental Section}

1,4-diazido-1,4-dideoxy-2,3- $O$-isopropylidene-L-threitol (11): A solution containing 1,4-di- $O$-methanesulfonyl-2,3- $O$-isopropylidene-L-threitol $(1.1 \mathrm{~g}, 3.45 \mathrm{mmol})$ and sodium azide $(898 \mathrm{mg}, 13.8 \mathrm{mmol})$ in dry DMF $(50 \mathrm{~mL})$ was stirred at $80-90^{\circ} \mathrm{C}$ for $20 \mathrm{~h}$. The solvent was removed under reduced pressure. The residue was diluted with water $(50 \mathrm{~mL})$ and extracted with ether $(3 \times 20 \mathrm{~mL})$. The organic layer was washed with brine, dried $\left(\mathrm{MgSO}_{4}\right)$, and evaporated in vacuo to give $\mathbf{1 1}$ as a pale yellow liquid $(590 \mathrm{mg}, 80 \%$ ), which was used in the next step without further purification. ${ }^{1} \mathrm{H} \mathrm{NMR}\left(\mathrm{CDCl}_{3}, 200 \mathrm{MHz}\right): \delta=4.03(\mathrm{~m}, 2 \mathrm{H}), 3.53(\mathrm{~m}, 2 \mathrm{H})$, $3.30(\mathrm{~m}, 2 \mathrm{H}), 1.44(\mathrm{~s}, 6 \mathrm{H}) ;{ }^{13} \mathrm{C} \mathrm{NMR}\left(\mathrm{CDCl}_{3}, 50 \mathrm{MHz}\right): \delta=110.04,76.61$, 51.22, 26.52. IR (neat): $\tilde{v}=2110,1384,1376 \mathrm{~cm}^{-1}$

Bisazafulleroid 12: A solution of the bisazide $11(138 \mathrm{mg}, 0.65 \mathrm{mmol})$ in chlorobenzene $(100 \mathrm{~mL})$ was added to a refluxing solution of $\mathrm{C}_{60}(360 \mathrm{mg}$, $0.5 \mathrm{mmol})$ in chlorobenzene $(260 \mathrm{~mL}$, deoxygenated) during a period of 45 min under a nitrogen atmosphere. After the addition, the reaction mixture was refluxed for $15 \mathrm{~h}$. The solvent was removed under reduced pressure, and the residue was subjected to flash column chromatography on silica gel. Elution with hexane/toluene $(20: 1)$ gave $100 \mathrm{mg}(28 \%)$ of unreacted $\mathrm{C}_{60}$. Further elution (hexane/toluene $\left.4: 1\right)^{[18]}$ afforded 12 as a black-brown solid $\left(65 \mathrm{mg}, 20 \%\right.$ based on reacted $\left.\mathrm{C}_{60}\right) \cdot{ }^{1} \mathrm{H}$ NMR $\left(\mathrm{CS}_{2} /\right.$ $\left.\mathrm{CDCl}_{3}, 500 \mathrm{MHz}\right): \delta=4.77-4.65(\mathrm{~m}, 3 \mathrm{H}), 4.38(\mathrm{dd}, J=10.6,1.3 \mathrm{~Hz}, 1 \mathrm{H})$, $3.84(\mathrm{dd}, J=13.0,5.8 \mathrm{~Hz}, 1 \mathrm{H}), 3.68(\mathrm{dd}, J=13.0,10.0 \mathrm{~Hz}, 1 \mathrm{H}), 1.63(\mathrm{~s}$, $3 \mathrm{H}), 1.61(\mathrm{~s}, 3 \mathrm{H}) ;{ }^{13} \mathrm{C} \mathrm{NMR}\left(\mathrm{CS}_{2} / \mathrm{CDCl}_{3}, 125 \mathrm{MHz}\right): \delta=155.99\left(\mathrm{dd}, J_{\mathrm{C}-\mathrm{N}}=\right.$ $10.4,4.1 \mathrm{~Hz}), 147.42,147.40,147.13,146.66,145.35,145.15,144.88,144.73$, $144.71,144.49,144.44,144.43$ (2C), 144.40, 144.34, 144.24, 144.20, 144.18, $144.17,144.00,143.78,143.74,143.68,143.62$ (2C), 143.61 (2C), 143.36, $143.34,143.32,143.23,142.89,142.60,142.57,142.26,141.86,141.61,141.58$, $141.49,141.34,141.00\left(\mathrm{~d}, J_{\mathrm{C}-\mathrm{N}}=1.6 \mathrm{~Hz}\right), 140.03,139.82,139.62,139.36$, $139.06,138.75\left(\mathrm{~d}, J_{\mathrm{C}-\mathrm{N}}=5.0 \mathrm{~Hz}\right), 137.80\left(\mathrm{~d}, J_{\mathrm{C}-\mathrm{N}}=3.5 \mathrm{~Hz}\right), 137.72(\mathrm{dd}$, $\left.J_{\mathrm{C}-\mathrm{N}}=6.6,2.4 \mathrm{~Hz}\right), 136.52,136.27\left(\mathrm{~d}, J_{\mathrm{C}-\mathrm{N}}=13.4 \mathrm{~Hz}\right), 135.96,135.69(\mathrm{~d}$, $\left.J_{\mathrm{C}-\mathrm{N}}=3.6 \mathrm{~Hz}\right), 135.66,134.41\left(\mathrm{~d}, J_{\mathrm{C}-\mathrm{N}}=1.9 \mathrm{~Hz}\right), 133.23,132.98\left(\mathrm{~d}, J_{\mathrm{C}-\mathrm{N}}=\right.$ $2.1 \mathrm{~Hz}), 132.53,130.04$ (broad), 111.10, $81.52\left(\mathrm{~d}, J_{\mathrm{C}-\mathrm{N}}=3.9 \mathrm{~Hz}\right), 78.37(\mathrm{~d}$, $\left.J_{\mathrm{C}-\mathrm{N}}=2.1 \mathrm{~Hz}\right), 52.22\left(\mathrm{~d}, J_{\mathrm{C}-\mathrm{N}}=7.5 \mathrm{~Hz}\right), 51.45\left(\mathrm{~d}, J_{\mathrm{C}-\mathrm{N}}=12.9 \mathrm{~Hz}\right), 26.87$, 26.82; FAB-MS (NBA): $m / z: 877.5\left[M^{+}+1\right]$.

Aza-aziridinofulleroid 13: A solution of the bisazafulleroid $12(65 \mathrm{mg})$ in $\mathrm{CH}_{2} \mathrm{Cl}_{2}$ (600 mL; a few drops of $\mathrm{CS}_{2}$ were added to ensure solubility) was kept exposed to ambient light. After $4 \mathrm{~h}$ TLC showed complete conversion to $\mathbf{1 3}$. Solvent was removed in vacuo at room temperature to give $\mathbf{1 3}$ as a brown solid. ${ }^{1} \mathrm{H} \mathrm{NMR}\left(\mathrm{CS}_{2} / \mathrm{CDCl}_{3}, 500 \mathrm{MHz}\right): \delta=5.07 \quad(\mathrm{dd}, J=10.0$, $5.7 \mathrm{~Hz}, 1 \mathrm{H}), 4.95(\mathrm{ddd}, J=10.0,8.8,5.7 \mathrm{~Hz}, 1 \mathrm{H}), 4.83(\mathrm{dt}, J=8.8,2.8 \mathrm{~Hz}$, $1 \mathrm{H}), 4.50(\mathrm{dd}, J=13.4,8.8 \mathrm{~Hz}, 1 \mathrm{H}), 4.44(\mathrm{dd}, J=13.4,2.8 \mathrm{~Hz}, 1 \mathrm{H}), 3.88(\mathrm{t}$, $J=10.0 \mathrm{~Hz}, 1 \mathrm{H}), 1.65(\mathrm{~s}, 3 \mathrm{H}), 1.62(\mathrm{~s}, 3 \mathrm{H}) ;{ }^{13} \mathrm{C} \mathrm{NMR}\left(\mathrm{CS}_{2} / \mathrm{CDCl}_{3}\right.$, $125 \mathrm{MHz}): \delta=148.65\left(\mathrm{~d}, J_{\mathrm{C}-\mathrm{N}}=5.3 \mathrm{~Hz}\right), 147.84,146.84,146.64,146.62$, 146.61, 146.45, 146.31, 146.01, 145.83, 145.52, 145.43, 145.42, 145.29, 145.27, $145.14,145.11,144.95,144.94,144.54,144.34,144.30,144.29,144.18,143.95$, $143.84,143.61,143.56,143.45$ (2C), 143.41, 143.24, 143.23, 142.85, 142.81, $142.55,142.42,142.40,142.30,142.06\left(\mathrm{~d}, J_{\mathrm{C}-\mathrm{N}}=2.6 \mathrm{~Hz}\right), 141.38,141.35$, $141.29,140.90,140.49,140.13,139.45\left(\mathrm{~d}, J_{\mathrm{C}-\mathrm{N}}=7.0 \mathrm{~Hz}\right), 139.33,139.00$, $138.06,138.00,137.99\left(\mathrm{~d}, J_{\mathrm{C}-\mathrm{N}}=6.0 \mathrm{~Hz}\right), 137.35,137.17,136.78,136.16$, $135.14,134.08\left(\mathrm{~d}, J_{\mathrm{C}-\mathrm{N}}=5.3 \mathrm{~Hz}\right), 111.57,80.30\left(\mathrm{~d}, J_{\mathrm{C}-\mathrm{N}}=9.2 \mathrm{~Hz}\right), 78.40(\mathrm{brs})$, $75.16\left(\mathrm{dd}, J_{\mathrm{C}-\mathrm{N}}=3.5,1.8 \mathrm{~Hz}\right), 69.0\left(\mathrm{dd}, J_{\mathrm{C}-\mathrm{N}}=10.1,4.1 \mathrm{~Hz}\right), 55.59\left(\mathrm{~d}, J_{\mathrm{C}-\mathrm{N}}=\right.$ $3.9 \mathrm{~Hz}), 51.50\left(\mathrm{dd}, J_{\mathrm{C}-\mathrm{N}}=7.9,3.2 \mathrm{~Hz}\right), 27.08,26.99$; FAB-MS (NBA): $m / z$ : $877.5\left[M^{+}+1\right]$.

Acknowledgments: This work was supported by the National Science Council of the Republic of China.

Received: March 24, 1998 [F1062]

[1] a) M. Prato, Q. C. Li, F. Wudl, V. Lucchini, J. Am. Chem. Soc. 1993 115, 1148; b) M. Takeshita, T. Suzuki, S. Shinkai, J. Chem. Soc. Chem. Commun. 1994, 2587; c) C. J. Hawker, P. M. Saville, J. W. White, J. Org. Chem. 1994, 59, 3503; d) M. R. Banks, J. I. G. Cadogan, I. Gosney, P. K. G. Hodgson, P. R. R. Langridge-Smith, J. R. A. Miller, A. T. Taylor, J. Chem. Soc. Chem. Commun. 1995, 885; e) G. Schick, T. Grösser, A. Hirsch, J. Chem. Soc. Chem. Commun. 1995, 2289; f) J. C. Hummelen, M. Prato, F. Wudl, J. Am. Chem. Soc. 1995, 117, 7003.

[2] a) T. Ishida, K. Tanaka, T. Nogami, Chem. Lett. 1994, 561; b) M. R. Banks, J. I. G. Cadogan, I. Gosney, P. K. G. Hodgson, P. R. R. Langridge-Smith, D. W. H. Rankin, J. Chem. Soc. Chem. Commun. 1994, 1365 ; c) M. R. Banks, J. I. G. Cadogan, I. Gosney, P. K. G. Hodgson, P. R. R. Langridge-Smith, J. R. A. Miller, A. T. Taylor, Tetrahedron Lett. 1994, 35, 9067; d) L.-L. Shiu, K.-M. Chien, T.-Y. Liu, T.-I Lin, G.-R. Her, S.-L. Huang, T.-Y. Luh, J. Chem. Soc. Perkin Trans. 1 1994, 23, 3355; e) M. Yan, S. X. Cai, J. F. W. Keana, J. Org. Chem. 1994, 59, 5951; f) J. Averdung, J. Mattay, D. Jacovi, W. Abraham, Tetrahedron 1995, 51, 2543; g) J. Averdung, H. Luftmann, J. Mattay, K.-U. Claus, W. Abraham, Tetrahedron Lett. 1995, 36, 2957; h) J. Averdung, H. Luftmann, I. Schlachter, J. Mattay, Tetrahedron 1995, 51, 6977; i) M. R. Banks, J. I. G. Cadogan, I. Gosney, A. J. Henderson, P. K. G. Hodgson, W. G. Kerr, A. Kerth, P. R. R. Langridge-Smith, J. R. A. Miller, A. R. Mount, J. A. Parkinson, A. T. Taylor, P. Thornburn Chem. Commun. 1996, 507; j) A. B. Smith, III, H. Tokuyama, Tetrahedron 1996, 52, 5257; k) J. Averdung, J. Mattay, Tetrahedron 1996, 52, 5407; 1) J. Averdung, C. Wolff, J. Mattay, Tetrahedron Lett. 1996, 37, 4683.

[3] a) T. Grösser, M. Prato, V. Lucchini, A. Hirsch, F. Wudl, Angew. Chem. 1995, 107, 1462; Angew. Chem. Int. Ed. Engl. 1995, 34, 1343; b) J. C. Hummelen, B. Knight, J. Pavlovich, R. González, F. Wudl, Science 1995, 269, 1554; c) L. Echegoyen, private communication.

[4] a) L.-L. Shiu, K.-M. Chien, T.-Y. Liu, T.-I. Lin, G.-R. Her, T.-Y. Luh, J. Chem. Soc. Chem. Commun. 1995, 1159; b) C. K.-F. Shen, K.-M. Chien, C.-G. Juo, G.-R. Her, T.-Y. Luh, J. Org. Chem. 1996, 61, 9242; c) G.-X. Dong, J.-S. Li, T.-H. Chan, J. Chem. Soc. Chem. Commun. 1995, 1725.

[5] C. K.-F. Shen, H.-H. Yu, C.-G. Juo, K.-M. Chien, G.-R. Her, T.-Y. Luh, Chem. Eur. J. 1997, 3, 744.

[6] a) I. Lamparth, B. Nuber, G. Schick, A. Skiebe, T. Grösser, A. Hirsch, Angew. Chem. 1995, 107, 2473; Angew. Chem. Int. Ed. Engl. 1995, 34 , 2257; b) G. Schick, A. Hirsch, H. Mauser, T. Clark, Chem. Eur. J. 1996, $2,935$.

[7] For a recent review, see: Y. Rubin, Chem. Eur. J. 1997, 3, 1009.

[8] a) T. Suzuki, Q. Li, K. C. Khemani, F. Wudl, O. Almarsson, Science 1991, 254, 1186; b) F. Wudl, Acc. Chem. Res. 1992, 25, 157.

[9] a) F. Diederich, L. Isaacs, D. Philp, Chem. Soc. Rev. 1994, 243, and references therein; b) A. B. Smith, R. B. Strongin, L. Brard, G. T. Furst, W. J. Romanow, K. G. Owens, R. J. Goldschmidt, R. C. King, J. Am. Chem. Soc. 1995, 117, 5492.

[10] R. A.-J. Janssen, J. C. Hummelen, F. Wudl, J. Am. Chem. Soc. 1995, $117,544$.

[11] M. Eiermann, F.Wudl, M. Prato, M. Maggini, J. Am. Chem. Soc. 1994, 116,8364 .

[12] a) R. Gonzalez, J. C. Hummelen, F. Wudl, J. Org. Chem. 1995, 60, 2618 ; b) J. C. Hummelen, B. W. Knight, F. LePeq, F. Wudl, J. Yao, C. L. Wlikins, J. Org. Chem. 1995, 60, 532.

[13] Z. Li, P. B. Shevlin, J. Am. Chem. Soc. 1997, 119, 1149.

[14] S. Berger, J. D. Roberts, J. Am. Chem. Soc. 1974, 96, 6757.

[15] It should be noted that one of the methylene carbons also showed long-range coupling indicating the proximity of this nitrogen. 
[16] L. A. Paquette, D. E. Kuhla, J. H. Barrett, J. Org. Chem. 1969, 34, 2879.

[17] a) A. Vasella, P. Uhlmann, C. A. Waldraff, F. Diederich, C. Thilgen, Angew. Chem. 1992, 104, 1383; Angew. Chem. Int. Ed. Engl. 1992, 31 , 1388; b) L. Isaac, F. Diederich, Helv. Chim. Acta 1993, 76, 2454; c) M. Prato, A. Bianco, M. Maggini, G. Scorrano, C. Toniolo, F. Wudl, J. Org. Chem. 1993, 58, 5578; d) S. R. Wilson, Y. Wu, N. A. Kaprinidis, D. I. Schuster, C. J. Welch, J. Org. Chem. 1993, 58, 6548; e) S. R. Wilson, Y. Wu, N. A. Kaprinidis, D. I. Schuster, J. Am. Chem. Soc. 1993, 115, 8495 ; f) S. R. Wilson, Q. Lu, J. Cao, Y. Wu, C. J. Welch, D. I. Schuster, Tetrahedron 1996, 52, 5131; g) J. M. Hawkins, A. Meyer, Science 1993,
260,1918; h) J. M. Hawkins, A. Meyer, M. Nambu, J. Am. Chem. Soc 1993, 115,9844 ; i) J. M. Hawkins, M. Nambu, A. Meyer, J. Am. Chem. Soc. 1994, 116, 7642; j) A. Hirsch, I. Lamparth, H. R. Karfunkel, Angew. Chem. 1994, 106, 453; Angew. Chem. Int. Ed. Eng. 1994, 33 437; k) M. Maggini, G. Scorrano, A. Bianco, C. Toniolo, M. Prato, Tetrahedron Lett. 1995, 36, 2845; 1) A. Herrmann, M. Rüttermann, C. Thilgen, F. Diederich, Helv. Chim. Acta 1995, 78, 1673; m) J. Averdung, C. Wolff, J. Mattay, Tetrahedron Lett. 1996, 37, 4683; n) C. Thilgen, A. Herrmann, F. Diederich, Helv. Chim. Acta 1997, 80, 183. [18] The solvent from the eluted fractions was removed immediately in vacuo and in the absence of light. 